Tohoku J. exp. Med., 1986, 148, 135-141

\title{
Familial Idiopathic Hypoparathyroidism and Progressive Sensorineural Deafness
}

\author{
Shigeru Yumita, Yohtaro Furukawa, Hyo Euy Sohn, \\ Hiroshi Unakami, Ryo Miura and Kaoru Yoshinaga \\ The Second Department of Internal Medicine, Tohoku \\ University School of Medicine, Sendai 980
}

\begin{abstract}
Yumita, S., Furukawa, Y., Sohn, H.E., Unakami, H., Miura, R. and Yoshinaga, K. Familial Idiopathic Hypoparathyroidism and Progressive Sensorineural Deafness. Tohoku J. exp. Med., 1986, $148(2), 135-141$ — Three cases from two families with idiopathic hypoparathyroidism and progressive sensorineural deafness are described. Cases 1 and 2 were siblings. Case 3 was one of four siblings from another family. All of them had both idiopathic hypoparathyroidism and progressive sensorineural hearing loss. There was no evidence to suggest involvement of autoimmune mechanism in these cases except for the associated Graves' hyperthyroidism in case 3. Human leukocyte antigen A9 and All were positive in both families. The sensorineural hearing loss was progressive even after the treatment for hypoparathyroidism. As the familial idiopathic hypoparathyroidism is a very rare entity, it is unlikely that this disease is associated with familial progressive sensorineural deafness by chance. The combination of these two diseases may compose a new syndrome._—_ familial idiopathic hypoparathyroidism; familial progressive sensorineural deafness; human leukocyte antigen
\end{abstract}

Deficiency of parathyroid hormone (PTH) secretion without a definite cause has been termed "idiopathic hypoparathyroidism". Usually, this disease occurs on a sporadic basis, and familial occurrence is very rare (Bronsky et al. 1968). In the present report, three cases from two families having both idiopathic hypoparathyroidism and progressive sensorineural deafness are described. This is the first report of the association of these two very rare clinical disorders.

\section{Case Report}

Case 1: a 50-year-old boy was referred to the Tohoku University Hospital on March 26, 1964 because of tetany and sensorineural hearing loss, 40-60 db in the left ear and more than $60 \mathrm{db}$ in the right. He had a history of convulsive seizures, and an electroencephalogram suggested a diagnosis of epilepsy of focal and centrencephalic types, but he was not treated by any anti-epileptic drugs. The

Received May 20, 1985; accepted for publication November 21, 1985.

*Part of the study was presented at the 8th International Conference on the Calcium Regulating Hormones, Kobe, Japan, October 16-24, 1983 (Abstract P-159). 
Chvostek and Trousseau phenomena were positive. There was no sign of pseudohypoparathyroidism or moniliasis. Physical examination revealed bilateral cataract and enamel aplasia of the teeth. The radiological examination of the head failed to reveal any intracranial calcification. But it was later detected by computerized axial tomography in 1979. Laboratory tests revealed normal hematological data. Serum calcium was $6.6 \mathrm{mg} / 100 \mathrm{ml}$ (normal $8.4-10.2 \mathrm{mg} / 100$ $\mathrm{ml}$ ), phosphate $9.9 \mathrm{mg} / 100 \mathrm{ml}$ (normal $2.8-4.4 \mathrm{mg} / 100 \mathrm{ml}$ ), $\mathrm{Mg} 1.5 \mathrm{mg} / 100 \mathrm{ml}, \mathrm{Na}$ $141 \mathrm{mEq} /$ liter, K $3.9 \mathrm{mEq} /$ liter and $\mathrm{Cl} 100 \mathrm{mEq} /$ liter. Total protein was $7.0 \mathrm{~g} /$ $100 \mathrm{ml}$, albumin $4.9 \mathrm{~g} / 100 \mathrm{ml}, \mathrm{BUN} 15 \mathrm{mg} / 100 \mathrm{ml}$. Liver function tests, oral glucose tolerance test, thyroid function and adrenal function were normal. The phosphate clearance was $4.6 \mathrm{ml} / \mathrm{min}$ and the percent tubular reabsorption of phosphate (\%TRP) was 94.0. Ellsworth-Howard test using $200 \mathrm{U}$ of Parathormone (Eli Lilly \& Co.) intravenously elicited a brisk phosphaturia (an increase of $70.7 \mathrm{mg}$ in $2 \mathrm{hrs}$ ). From these data, he was diagnosed as having idiopathic hypoparathyroidism (Yamamoto et al. 1977). The parathyroid antibody was negative, and human leukocyte antigen (HLA) typing was A9, 11/B15, w51/C3, - . After the treatment with dihydrotachysterol, the concentration of serum calcium and phosphate were normalized, but sensorineural hearing loss remained progressive. He had later married a healthy woman and got a child. Up to the present day, this child has shown neither tetany nor hearing loss.

Case 2 : a 28 -year-old house wife, who is a younger sister of case 1, visited our hospital on May 25, 1982, for the detailed examinations on hyperthyroidism which had been diagnosed for the 10 years, and on bilateral 40-60 db sensorineural hearing loss which had started in her childhood. She was a sister of case 1, and had a history of several attacks of tetany after her first childbirth. The Chvostek and Trousseau phenomena were negative, and she had no cataract, intracranial calcification or moniliasis. Laboratory tests revealed normal hematological data. Serum calcium was $7.1 \mathrm{mg} / 100 \mathrm{ml}$, phosphate $4.8 \mathrm{mg} / 100 \mathrm{ml}, \mathrm{Mg} 1.8 \mathrm{mg} / 100 \mathrm{ml}$, $\mathrm{Na} 138 \mathrm{mEq} /$ liter, $\mathrm{K} 4.0 \mathrm{mEq} /$ liter and $\mathrm{Cl} 101 \mathrm{mEq} /$ liter. Total protein was 7.5 $\mathrm{g} / 100 \mathrm{ml}$, albumin $4.3 \mathrm{~g} / 100 \mathrm{ml}$, BUN $15 \mathrm{mg} / 100 \mathrm{ml}$, uric acid $5.8 \mathrm{mg} / 100 \mathrm{ml}$ and creatinine $0.9 \mathrm{mg} / 100 \mathrm{ml}$. The circulating PTH measured by radioimmunoassay (iPTH) using antibody mainly recognizing the $\mathrm{C}$ terminal portion of the molecule (Yumita et al. 1983) was undetectable (less than $0.10 \mathrm{ng} / \mathrm{ml}$, normal $0.20-0.44 \mathrm{ng}$ / $\mathrm{ml}$ ). Nephrogenous cyclic adenosine monophosphate (NcAMP) (Broadus et al. 1977) was $3.32 \mathrm{nmol} / 100 \mathrm{ml} \mathrm{GF} \mathrm{(normal} \mathrm{0.78-2.80} \mathrm{nmol/100} \mathrm{ml} \mathrm{GF),} \mathrm{the} \mathrm{elevated}$ level of which seemed to be due to the coexistent hyperthyroidism. The phosphate clearance was $5.5 \mathrm{ml} / \mathrm{min}$ and \% TRP was 92.0. Physical examination disclosed a diffuse thyroid enlargement. The basal metabolic rate was $+59 \%$. Serum triiodothyronine and thyroxine were $327 \mathrm{ng} / 100 \mathrm{ml}$ and $21.5 \mathrm{ug} / 100 \mathrm{ml}$, respectively, and thyrotropin was undetectable. Therefore, she was treated with radiations under the diagnosis of Graves' disease. The exogenous PTH (Synthetic hPTH (1-34) 100 U, Toyo Jyozo Co. (Igarashi et al. 1982)) administered in 


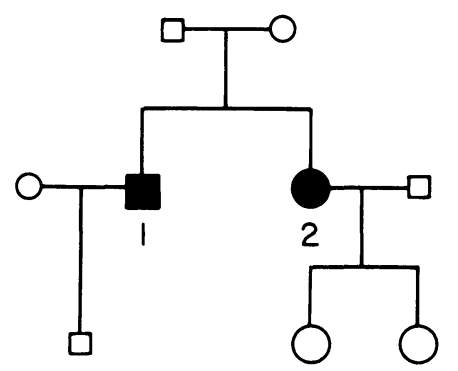

Fig. 1. Pedigree of the family 1.

Squares represent males and circles females. Numbers indicate the case numbers. Closed symbols represent persons with hypocalcemia, and smaller symbols represent persons not studied for serum calcium. The persons with sensorineural hearing loss have asterisks on the right side.

TABle 1. Parathyroid function test in family 1

\begin{tabular}{lccc}
\hline & & Case 1 & Case 2 \\
\hline Calcium & $(\mathrm{mg} / 100 \mathrm{ml})$ & 6.6 & 7.1 \\
Phosphate & $(\mathrm{mg} / 100 \mathrm{ml})$ & 9.9 & 4.8 \\
Magnesium & $(\mathrm{mg} / 100 \mathrm{ml})$ & 1.5 & 1.8 \\
Phosphate clearance & $(\mathrm{ml} / \mathrm{min})$ & 4.6 & 5.5 \\
\%TRP & $(\mathrm{ng} / \mathrm{ml})$ & 94.0 & 92.0 \\
iPTH & $(\mathrm{nmol} / 100 \mathrm{ml} \mathrm{GF})$ & nd & nd \\
NcAMP & & & 3.32 \\
Ellsworth-Howard test & $(\mu \mathrm{mol})$ & & 14.01 \\
\multicolumn{1}{c}{$\Delta$ cAMP } & $(\mathrm{mg})$ & 70.7 & 35.2 \\
\hline P & & & \\
\hline
\end{tabular}

\%TRP: Percent tubular reabsorption of phosphate.

iPTH: The circulating parathyroid hormone measured by radioimmunoassay using antibody mainly recognizing the carboxy terminal portion of the molecule; nd means "not detectable".

NcAMP: Nephrogenous cyclic adenosine monophosphate; the increased NcAMP in case 2 seemed to be due to the coexistent hyperthyroidism.

Ellsworth-Howard tests were performed with Parathormone (Eli Lilly \& Co.) in case 1 and with synthetic hPTH (1-34) (Toyo Jyozo Co.) in case 2. $\Delta$ cAMP means the $1-\mathrm{hr}$ increment of the urinary cAMP excretion and $\Delta \mathrm{P}$ means the $2-\mathrm{hr}$ increment of the urinary phosphate excretion after the administration of exogenous PTH.

the same manner as in case 1, elicited a hyperresponsiveness ; 2-hr increment of urinary phosphate excretion was $35.2 \mathrm{mg}$ and 1-hr increment of urinary cyclic adenosine monophosphate (cAMP) excretion was $14.01 \mu \mathrm{mol}$. From these results, she was diagnosed as familial idiopathic hypoparathyroidism with familial progressive sensorineural deafness as in case 1. The parathyroid antibody was negative and HLA typing was A9, 11/B15, w51/C3,-. She was treated with $1 \alpha$, 25-dihydroxyvitamin $\mathrm{D}_{3}$. The concentrations of serum calcium and phosphate 


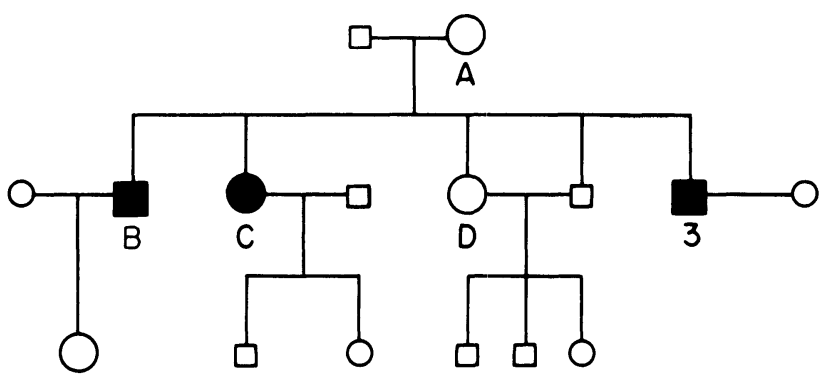

Fig. 2. Pedigree of the family 2.

The symbols with letters A, B, C and D were described in the text.

TABle 2. Parathyroid function test in family 2

\begin{tabular}{|c|c|c|c|c|c|c|}
\hline & & Case 1 & $\mathrm{~A}$ & B & $\mathrm{C}$ & $\mathrm{D}$ \\
\hline Calcium & $(\mathrm{mg} / 100 \mathrm{ml})$ & 5.5 & 8.8 & 6.4 & 6.0 & 8.5 \\
\hline Phosphate & $(\mathrm{mg} / 100 \mathrm{ml})$ & 6.1 & 3.8 & 4.3 & 3.9 & 3.6 \\
\hline Magnesium & $(\mathrm{mg} / 100 \mathrm{ml})$ & 2.4 & & & & \\
\hline Phosphate clearance & $(\mathrm{ml} / \mathrm{min})$ & 3.5 & & & & \\
\hline$\% \mathrm{TRP}$ & & 95.8 & & & & \\
\hline iPTH & $(\mathrm{ng} / \mathrm{ml})$ & nd & 0.22 & nd & nd & 0.24 \\
\hline NcAMP & $(\mathrm{nmol} / 100 \mathrm{ml} \mathrm{GF})$ & 0.29 & & & & \\
\hline 25-hydroxyvitamin D & $(\mathrm{ng} / \mathrm{ml})$ & 8.9 & & & & \\
\hline 24, 25-dihydroxyvitamin D & $(\mathrm{ng} / \mathrm{ml})$ & 1.62 & & & & \\
\hline 1, 25-dihydroxyvitamin D & $(\mathrm{pg} / \mathrm{ml})$ & nd & & & & \\
\hline \multicolumn{7}{|l|}{ Ellsworth-Howard test } \\
\hline$\triangle \mathrm{cAMP}$ & $(\mu \mathrm{mol})$ & 7.02 & & & & \\
\hline$\Delta \mathrm{P}$ & $(\mathrm{mg})$ & 73.4 & & & & \\
\hline
\end{tabular}

The letters A, B, C, and D represent the relatives of the case 3 as shown in Fig. 2 . Ellsworth-Howard test was performed with hPTH (1-34) in case 3.

were normalized, but sensorineural hearing loss was progressive. She had been married with healthy man and had two children. These children showed neither tetany nor hearing loss. The family pedigree of cases 1 and 2 is shown in Fig. 1, and the results of the parathyroid function tests are summarized in Table 1.

Case 3: a 29-year-old man visited our hospital on February 3, 1981 with tetany and bilateral 40-60 db sensorineural hearing loss which started since 14 years old. The Chvostek phenomenon was positive, but the Trousseau phenomenon was negative. There were no stigmata of pseudohypoparathyroidism. The physical examination revealed bilateral cataract, and calcification of the basal ganglia was detected by means of the computerized axial tomography of the head. Routine laboratory testing revealed normal hematological data. Serum calcium was $5.5 \mathrm{mg} / 100 \mathrm{ml}$, phosphate $6.1 \mathrm{mg} / 100 \mathrm{ml}, \mathrm{Mg} 2.4 \mathrm{mg} / 100 \mathrm{ml}, \mathrm{Na}, 144 \mathrm{~m} \mathrm{Eq} /$ 
liter, $\mathrm{K} 4.3 \mathrm{mEq} /$ liter and $\mathrm{Cl} 100 \mathrm{mEq} /$ liter. Total protein was $7.4 \mathrm{~g} / 100 \mathrm{ml}$, albumin $4.8 \mathrm{~g} / 100 \mathrm{ml}$, BUN $13 \mathrm{mg} / 100 \mathrm{ml}$, uric acid $5.9 \mathrm{mg} / 100 \mathrm{ml}$ and creatinine $1.2 \mathrm{mg} / 100 \mathrm{ml}$. Endogenous creatinine clearance was $79 \mathrm{ml} / \mathrm{min}$ and renal plasma flow was $358 \mathrm{ml} / \mathrm{min}$. The impaired renal functions seemed to be due to aplasia or hypoplasia of the right kidney which was diagnosed subsequently by the computerized axial tomography, renoscintigraphy and renography. LDH and CPK were 651 and $740 \mathrm{IU} /$ liter respectively, which seemed to originate from the striated muscles due to tetany. The remaining biochemical function tests for liver and kidney were within normal limits. Oral glucose tolerance test gave normal results with regard to blood sugar and insulin responses. Thyroid, adrenal and pituitary functions were normal before and after various stimulation tests. The phosphate clearance was $3.5 \mathrm{ml} / \mathrm{min}$ and \% TRP was 95.8 . The circulating iPTH was undetectable and NcAMP was $0.29 \mathrm{nmol} / 100 \mathrm{ml} \mathrm{GF}$. Plasma vitamin D metabolites measured according to the method described previously were 25-hydroxyvitamin D $8.9 \mathrm{ng} / \mathrm{ml}, 24,25$-dihydroxyvitamin D $1.62 \mathrm{ng} / \mathrm{ml}$ and 1 , 25-dihydroxyvitamin D undetectable (Unakami et al. 1982). He showed hyperresponsiveness to the synthetic hPTH (1-34); two hours increment of the urinary phosphate excretion was $73.4 \mathrm{mg}$ and 1-hr increment of the urinary cAMP excretion was $7.02 \mu \mathrm{mol}$, and the diagnosed of idiopathic hypoparathyroidism was made. The parathyroid antibody was negative, and no moniliasis was found. HLA typing was A9, 11/B5, 40/C-, -. The concentrations of serum calcium and phosphate were normalized by the treatment with $1 \alpha$-hydroxyvitamin $\mathrm{D}_{3}$, but sensorineural hearing loss was progressive. He had married a healthy woman for several years, but had no children. Through the seminal fluid examination, a diagnosis of azoospermia was made. On the examination of his family members, it was found that his brother and one of his sisters also had hypocalcemia $(6.4 \mathrm{mg}$ / $100 \mathrm{ml}$ in case $\mathrm{B}$ and $6.0 \mathrm{mg} / 100 \mathrm{ml}$ in case C in Fig. 2) and undetectable levels of circulating iPTH. His mother and another sister was normocalcemic $(8.8 \mathrm{mg} / 100$ $\mathrm{ml}$ of case $\mathrm{A}$ and $8.5 \mathrm{mg} / 100 \mathrm{ml}$ of case $\mathrm{D})$. They did not agree to take any provocative tests for hypoparathyroidism because they had no symptoms of hypocalcemia. Since all of his siblings, his father and one of his nieces had sensorineural hearing loss, he was also diagnosed as having familial idiopathic hypoparathyroidism and familial progressive sensorineural deafness. The family pedigree of case 3 is shown in Fig. 2, and the results of the parathyroid function tests in case 3 and his relatives are summarized in Table 2.

\section{Discussion}

Three cases from two families with idiopathic hypoparathyroidism and progressive sensorineural deafness were presented. Case 1 and 2 were siblings having idiopathic hypoparathyroidism and progressive sensorineural deafness. Case 3 was one of four siblings from another family. All of his siblings, his father and one of his nieces had progressive sensorineural hearing loss, and his brother 
and one of his sisters also had idiopathic hypoparathyroidism. Familial occurrence of idiopathic hypoparathyroidism is extremely rare. The diagnosis of "familial progressive sensorineural deafness" is made in the patients who have no other physical disturbances except sensorineural hearing loss and it appears in a family and progresses gradually (Paparella et al. 1969). It is well known that familial sensorineural deafness associated with other hereditary disorders, e.g. the association with hereditary nephritis or with familial goiter is called as Alport's syndrome (Williamson 1961) or Pendred's syndrome (Fraser et al. 1960), respectively. It has been suspected that there is an autoimmune basis for familial idiopathic hypoparathyroidism by the presence of antibodies directed against parathyroid tissue (Blizzard et al. 1966). Although there is an clinical entity of autoimmune sensorineural hearing loss (McCabe 1979), the autoimmune mechanism has not yet been confirmed in the familial progressive sensorineural deafness. The same explanation is possible for azoospermia in the case 3 . It has been emphasized that in general azoospermia due to antibodies against spermatozoa does not seem closely relating to the other organ-specific autoimmune diseases (Volpé 1981). In the present cases, the parathyroid antibodies were negative and there were no findings suggesting the contribution of the autoimmune mechanism for idiopathic hypoparathyroidism and sensorineural hearing loss, although the Graves' disease, so-called autoimmune hyperthyroidism, was found in case 2.

Barakat et al. (1977) described two male siblings with nephrotic syndrome, nerve deafness, and hypoparathyroidism. Both children, five and eight years of age, died of renal failure. The clinical course of the disease was consistent with familial nephrosis. It was demonstrated at autopsy that the parathyroid glands were absent in one child and hypoplastic in the other. The presence of the thymus gland and an intact cell-mediated immunity in these children exclude the Di George syndrome. These cases may be distinguished from the present cases, since the latter have normal renal functions and have no relatives who nephrosis. The renal functions were impaired in the case 3 , but they were due to aplasia or hypoplasia of the right kidney.

Brookes (1983) reported that vitamin D deficiency is a possible cause of cochlear deafness. Nevertheless, sensorineural hearing loss in the present cases was progressive even after treatment for hypoparathyroidism with active form of vitamin $\mathrm{D}$, and there were relatives having sensorineural hearing loss without hypoparathyroidism. Therefore, the sensorineural hearing loss in the present cases may not be induced by hypocalcemia due to hypoparathyroidism. Moreover, the otosclerosis is ruled out from the age of onset, absence of air-bone gap in the audiometry, and radiological examinations of the ear.

Familial idiopathic hypoparathyroidism is a very rare disorder. It seems unlikely that familial idiopathic hypoparathyroidism and familial progressive sensorineural deafness are associated by chance in both families. There is a possibility that the combination of these disorders constitutes a new syndrome. 
From this point of view, it is interesting that HLA A9 and A11 are positive in both of two families. They may play an important role in this proposed new syndrome.

\section{References}

1) Barakat, A.Y., D'Albora, J.B., Martin, M.M. \& Jose, P.A. (1977) Familial nephrosis, nerve deafness, and hypoparathyroidism. J. Pediat., 91, 61-64.

2) Blizzard, R.M., Chee, D. \& Davis, W. (1966) The incidence of parathyroid and other antibodies in the sera of patients with idiopathic hypoparathyroidism. Clin. exp. Immunol., 1, 119-128.

3) Brookes, G.B. (1983) Vitamin D deficiency - a new cause of cochlear deafness. $J$. Laryng. Otol., 97, 405-420.

4) Broadus, A.E., Mahaffey, J.E., Neer, R.M. \& Bartter, F.C. (1977) Nephrogenous cyclic AMP as a parathyroid function test. J.clin. Invest., 60, 771-783.

5) Bronsky, D., Kiamko, R.T. \& Waldstein, S.S. (1968) Familial idiopathic hypoparathyroidism. J. clin. Endocr., 18, 61-65.

6) Fraser, G.R., Morgan, M.E. \& Trotter, W.R. (1960) The syndrome of sporadic goitre and congenital deafness. Quart. J. Med., 29, 279-295.

7) Igarashi, T., Yamamoto, M., Yamada, M., Ogata, E. \& Katsuragi, S. (1982) Application of newly synthesized 1-34 human parathyroid hormone for diagnostic tests. Pharmatherapeutica, 3, 79-85.

8) McCabe, B.F. (1979) Autoimmune sensorineural hearing loss. Ann. Otol., 88, 585589.

9) Paparella, M.M., Sugiura, S. \& Hashino, T. (1969) Familial progressive sensorineural deafness. Arch. Otolaryng., 90, 70-77.

10) Unakami, H., Furukawa, Y., Sohn, H.E., Yumita, S., Miura, R., Hanew, K. \& Yoshinaga, K. (1982) Stimulation of 1, 25-dihydroxyvitamin D production by parathyroid hormone and dibutyryl $3^{\prime}, 5^{\prime}$-cyclic AMP in normal subjects, hypoparathyroidism and pseudohypoparathyroidism. Tohoku J. exp. Med., 138, 167-175.

11) Volpé, R. (1981) Immunological aspects of male infertility. In: Monographs on Endocrinology, edited by F. Gross, M.M. Grumbach, A. Labhart, M.B. Lipsett, T. Mann, L.T. Samuels \& J. Zander, Vol. 20. Auto-immunity in the endocrine system, edited by R. Volpé, Springer-Verlag, Berlin-Heidelberg-New York, pp. 176-177.

12) Williamson, D.A.J. (1961) Alport's syndrome of hereditary nephritis with deafness. Lancet, 2, 1321-1323.

13) Yamamoto, M., Furukawa, Y., Ogata, E. \& Fujita, T. (1977) A recomanded procedure of Ellsworth-Howard test and its problems. Saishin Igaku, 23, 2023-2029. (Japanese)

14) Yumita, S., Sohn, H.E., Miura, R. \& Furukawa, Y. (1983) The fundamental and clinical studies on human parathyroid hormone radioimmunoassay kit. Clin. Endocr., 31, 233-238. (Japanese) 